\title{
Prevalence of Mental Distress and Its Correlates among Assiut University Students
}

\author{
Sabra M. Ahmed and Hala H. Abou-Faddan
}

Public Health and Community Medicine Department, Assiut University, Egypt

Received: October, 2017 Accepted: December, 2017

\begin{abstract}
Objective: To estimate the prevalence and socio-demographic correlates of mental distress among Assiut university students. Methods: A cross-sectional descriptive study was carried out. A multi-stage stratified cluster sampling technique was used. Data were collected by using self-administered questionnaire. The questionnaire included the sociodemographic characteristics of the students in addition to a group of questions derived from the self-reporting questionnaire (SRQ-20) that was developed by the WHO to screen for mental disturbances especially in developing countries. Results: This study included 828 of Assiut University students. Mental distress was diagnosed in $17.1 \%$ of students. By logistic regression analysis, university or higher education of the parents and higher educational achievement in the past year were protective from mental distress. On the other hand, female gender, bad perceived health status, previous exposure to violence and family history of mental health problems were significantly associated with presence of mental distress among the studied group. An intervention program is recommended to raise the awareness about the importance of mental health status among students, parents and university administrators and to overcome factors associated with mental distress.
\end{abstract}

Key words: Mental distress, Assiut University students, Prevalence, Correlates.

Corresponding author: Sabra M. Ahmed E mail: . sabraa16@gmail com

\section{Introduction}

Mental distress is widespread globally, affecting over $25 \%$ of all people during their lives. Mental health distress is prevalent affecting people of all countries irrespective of age, sex and income. ${ }^{1}$

Mental health is defined as "performance of mental functions of thought, mood, and behavior successfully that causes productive actions, satisfying relationships with others, the capability to adjust and successfully deal with trouble/difficulty". 2 On the other hand, mental distress is defined as unpleasant mental or emotional status, damaging/weakening person's ability to successfully deal with day-to-day living. ${ }^{3}$ The prevalence of mental illness is about $10 \%$ in the adult population, and about
$20 \%$ of all patients who were observed by primary health care physicians have one or more mental health problems. ${ }^{1}$ Many studies revealed that prevalence of mental distress was higher among students than most people. ${ }^{4}$ Changing social and emotional picture of university students' causes that they become capable of being hurt for developing mental health problems. ${ }^{5}$

Mental distress has a greater negative consequence on role functioning as many serious chronic diseases. ${ }^{6}$ Mental health condition has great effect on university students' functioning. At the individual level, they have an effect on all features of physical, emotional, thinking-related and interpersonal functioning. They

No. 3 July 2018


might also have a negative effect on the scholastic performance. ${ }^{7}$

Little is known about the prevalence and risk factors of mental distress among Assiut university students. Therefore, this study was conducted to assess the prevalence and correlates of mental distress among Assiut university students.

The general objective is to promote proper mental health status among Assiut university students.

The specific objectives are (1) To estimate the prevalence of mental distress among Assiut university students (2) To study the socio-demographic and environmental correlates of mental distress among Assiut university students.

\section{Methods:}

Study design: a cross - sectional study design was carried out. Study site: The study was carried out in Assiut university which contains 18 faculties. The target population was Assiut university students. Administrative permission was taken before the start of the study from Dean of the faculties under study.

Sample size: Sample size was calculated using EPI INFO version 3.5.1 (2008). Sample size calculation was based on prevalence of mental distress of 50\% (P $=0.5)$ as a conservative guess for the prevalence of mental distress among the study population. With a power of $80 \%$ and confidence level of $95 \%$ and a design effect of 2, the sample needed for the study was 768 students. The sample was increased to 828 to compensate for dropouts.

Sampling Method: Target students were selected randomly by using a multi stage stratified cluster sampling technique. At the first stage, faculties within Assiut university was stratified into 3 strata; theoretical, representing $46 \%$ of the students (Commerce, Education, Law, Social Service and Literature); practical, representing $34 \%$ of the students (Agriculture, Science, Engineering, Vocational Education and Computer Science) and medical, representing 20\% of the students (Medicine, Pharmacy, Dentistry, Nursing and Veterinary Medicine). Then one faculty was chosen randomly from each stratum to end up with 3 faculties. In the second stage, a cluster sample was chosen from the second year within each faculty (practical sections or small classes). The sample was distributed proportionately between the three strata: 384 students (10 classes) from a theoretical faculty (Social Service), 282 students (8 classes) from a practical faculty (Engineering) and 162 students (5 classes) from a medical (Medicine) faculty.

The clusters (classes) were chosen through simple random sample. The second year was chosen to avoid high mental stress which may be present among early and final years.

Data collection: A self-administered questionnaire was used to collect the relevant data. The researchers distributed the questionnaires to the students. The aim of the study and any students' questions were clarified by the researchers. After filling the questionnaires (which was taking about 15 minutes of time) by the students, they were collected by the researchers.

Out of 900 questionnaires distributed to students, the returned complete questionnaires were 828 with a response rate of $92 \%$. Data collection was conducted between March 5, and May 4, 2017.

The questionnaire used in this study was divided into two sections: The first section included the socio-demographic information about students (age, gender, family residence, education and occupation of the parents, perceived health status, smoking and drug abuse among students ......etc). The second section was about assessment of mental 
health status of the students by using the Self Reporting Questionnaire (SRQ- 20) developed by World Health Organization to screen for more common mental distress in low income and developing countries. $^{8}$ The SRQ consists of 20 questions which have to be answered by yes or no. A respondent' score is the total number of questions to which he or she answered yes. The tool is designed so that the higher the score, the more likely that the respondent to have mental distress. A cutoff score of 8 was used by this study which is similar to that followed by Survey of Young People in Egypt (SYPE), 2014. ${ }^{9}$

Pilot study: the questionnaire was pretested on 20 students from Assiut faculty of medicine to assess the clarity of the questions and to identify any logistic problem. Necessary modification was applied before starting final data collection. Those students were not included in the main survey.

Statistical analysis: Data management and analysis was done by using SPSS program, version 20. Frequencies were reported as percentages; comparisons between frequency-based data were performed using $\chi^{2}$-test. Continuous variables were compared using twotailed independent-sample t-tests. For all comparisons, the statistical level of significance was set at $\mathrm{p}<0.05$. Multivariate logistic regression analysis was performed for significant variables. The dependent variable was mental health status (presence or absence of mental distress) and the independent variables were various sociodemographic variables

Ethical consideration: The research proposal was reviewed and approved by the Ethical Review Committee of Assiut Faculty of Medicine. The aim of the study was explained to participants before filling the questionnaire. Informed consent was obtained from those who accepted to participate in the study.
Anonymous questionnaire was used for data collection. Confidentiality of the data was maintained all over the study.

\section{Results:}

Table (1) shows the socio-demographic characteristics of students under the study in Assiut university. This study included 828 students, of them about one half $(46.4 \%)$ from faculty of social service, one third $(34.1 \%)$ from faculty of engineering and one fifth (19.6\%) from faculty of medicine. One half $(51.2 \%)$ were males, and $56 \%$ of them were from urban areas. The mean age of students was 20.6 years. One quarter of them had excellent or very good degree in the past year. Regarding education of parents, $15.4 \%$ of fathers were illiterate or only can read and write whereas one half $(50.8 \%)$ of them had university or higher education, one quarter $(24.4 \%)$ of mothers were illiterate or only read and write and $40.6 \%$ had university or higher education. Regarding occupation of parents, 68.3 and $37.2 \%$ of fathers and mothers were employees. Most of students $(71.9 \%)$ live with their families. The majority of students (93\%) were single. Mental distress was present among $17.1 \%$ of students.

Table (2) shows distribution of mental distress among students by sociodemographic characteristics. Female gender, rural and failed students had significantly high prevalence of mental distress $(21.8 \%, 20.8$ and $37.5 \%)(\mathrm{P}=$ $0.001,0.014$ and 0.001 ) respectively. Students whose fathers and mothers were illiterate or read and write had significantly higher prevalence $(28.1 \%$ and $24.8 \%$ ) of mental distress ( $\mathrm{P}=0.001$ and 0.002 respectively). Students whose mothers were housewives had significantly higher prevalence $(20.8 \%)$ of mental distress $(\mathrm{P}<0.001)$.

Table (3) shows that students with better perceived health status (excellent or very good) had significantly lower $(6.1 \%)$ 
Table (1): Socio-demographic characteristics of studied students, Assiut university, 2017.

\begin{tabular}{|c|c|}
\hline Characteristics & No. of students (\%) \\
\hline $\begin{array}{l}\text { Faculty: } \\
\text { - Faculty of Social Service } \\
\text { - Faculty of Engineering } \\
\text { - Faculty of Medicine }\end{array}$ & $\begin{array}{l}384(46.4) \\
282(34.1) \\
162(19.6)\end{array}$ \\
\hline $\begin{array}{l}\text { Sex: } \\
\text { - Males } \\
\text { - Females }\end{array}$ & $\begin{array}{l}424(51.2) \\
404(48.8)\end{array}$ \\
\hline Age $($ mean \pm SD): & $20.6 \pm 1.3$ \\
\hline $\begin{array}{l}\text { Family residence: } \\
\text { - Urban } \\
\text { - Rural }\end{array}$ & $\begin{array}{l}462(55.8) \\
366(44.2)\end{array}$ \\
\hline $\begin{array}{l}\text { Grades of past year: } \\
\text { - Excellent / Very Good } \\
\text { - Good } \\
\text { - Pass } \\
\text { - Failed (Repeat the same grade) }\end{array}$ & $\begin{array}{r}216(26.1) \\
364(44.0) \\
232(28.0) \\
16(1.9)\end{array}$ \\
\hline $\begin{array}{l}\text { Education of the father: } \\
\text { - Illiterate / Read \& write } \\
\text { - Basic / Secondary } \\
\text { - University / Higher education }\end{array}$ & $\begin{array}{l}128(15.4) \\
280(33.8) \\
420(50.8) \\
\end{array}$ \\
\hline $\begin{array}{l}\text { Education of the mother: } \\
\text { - Illiterate /Read \& write } \\
\text { - Basic / Secondary } \\
\text { - University / Higher education }\end{array}$ & $\begin{array}{l}202(24.4) \\
290(35.0) \\
336(40.6)\end{array}$ \\
\hline $\begin{array}{l}\text { Occupation of the father: } \\
\text { - Employee } \\
\text { - Worker } \\
\text { - Farmer } \\
\text { - Died }\end{array}$ & $\begin{array}{r}566(68.3) \\
152(18.3) \\
60(7.2) \\
50(6.0) \\
\end{array}$ \\
\hline $\begin{array}{l}\text { Occupation of the mother: } \\
\text { - Housewife } \\
\text { - Employee }\end{array}$ & $\begin{array}{l}520(62.8) \\
308(37.2)\end{array}$ \\
\hline $\begin{array}{l}\text { Presence of sibling: } \\
\begin{array}{ll}\text { - No } & \\
\text { - Yes } & \\
& \bullet \text { Males }(\text { mean } \pm \text { SD) } \\
& \bullet \text { Females }(\text { mean } \pm \text { SD) }\end{array}\end{array}$ & $\begin{aligned} & 30(3.6) \\
& 798(96.4) \\
1.7 \pm & 1.3 \\
1.8 \pm & 1.5\end{aligned}$ \\
\hline
\end{tabular}


Table (1): Socio-demographic characteristics of studied students, Assiut university, 2017, continued.

\begin{tabular}{|c|c|}
\hline Characteristics & No. of students (\%) \\
\hline $\begin{array}{l}\text { Student live with: } \\
\text { - } \quad \text { The family } \\
\text { - } \quad \text { Away from his /her family }\end{array}$ & $\begin{array}{l}596(71.9) \\
232(29.1)\end{array}$ \\
\hline $\begin{array}{ll}\text { Preference: } \\
\text { - } \quad \text { Daughter like son } \\
\text { - } \quad \text { Family prefers son } \\
\text { - } \quad \text { Family prefers daughter }\end{array}$ & $\begin{array}{r}766(92.5) \\
58(7.0) \\
4(0.5)\end{array}$ \\
\hline $\begin{array}{ll}\text { Marriage: } \\
-\quad \text { Single } \\
-\quad \text { Engaged } \\
-\quad \text { Married }\end{array}$ & $\begin{array}{r}770(93.0) \\
58(5.8) \\
10(1.2)\end{array}$ \\
\hline $\begin{array}{c}\text { Consanguinity among parents: } \\
\bullet \quad \text { First degree } \\
\bullet \quad \text { Second degree } \\
\end{array}$ & $\begin{array}{l}280(33.8) \\
164(58.5) \\
116(41.5) \\
\end{array}$ \\
\hline $\begin{array}{l}\text { Perceived health status of the student: } \\
\text { - } \quad \text { Excellent / Very good } \\
\text { - } \quad \text { Good } \\
\text { - } \quad \text { Average (fair) / Bad }\end{array}$ & $\begin{array}{l}392(47.3) \\
306(37.0) \\
130(15.7)\end{array}$ \\
\hline Presence of disability: & $20(2.4)$ \\
\hline Smoking: & $124(15.0)$ \\
\hline Drug abuse: & $16(1.9)$ \\
\hline Exposure to violence: & $122(14.7)$ \\
\hline Family history of mental health problems: & $90(10.9)$ \\
\hline $\begin{array}{l}\text { Mental distress: } \\
-\quad \text { Yes }(\geq 8) \\
-\quad \text { No }(<8)\end{array}$ & $\begin{array}{l}142(17.1) \\
686(82.9)\end{array}$ \\
\hline Tota1 & $828(100.0)$ \\
\hline
\end{tabular}


Table (2): Distribution of mental distress among studied students by sociodemographic characteristics, Assiut university, 2017.

\begin{tabular}{|c|c|c|c|}
\hline \multirow{2}{*}{ Characteristics } & \multicolumn{2}{|c|}{ Presence of mental distress } & \multirow{2}{*}{ P - value } \\
\hline & Yes & No & \\
\hline $\begin{array}{ll}\text { Faculty: } \\
\text { - } & \text { Faculty of Social Service } \\
- & \text { Faculty of Engineering } \\
- & \text { Faculty of Medicine }\end{array}$ & $\begin{array}{l}48(17.0) \\
66(17.2) \\
28(17.3)\end{array}$ & $\begin{array}{l}234(83.0) \\
318(82.8) \\
134(82.7)\end{array}$ & 0.999 \\
\hline Age of student (Mean \pm SD) & $20.6 \pm 1.4$ & $20.6 \pm 1.3$ & 0.387 \\
\hline $\begin{array}{l}\text { Sex: } \\
-\quad \text { Males } \\
-\quad \text { Females } \\
\end{array}$ & $\begin{array}{l}54(12.7) \\
88(21.8)\end{array}$ & $\begin{array}{l}370(87.3) \\
316(78.2) \\
\end{array}$ & 0.001 \\
\hline $\begin{array}{l}\text { Family residence: } \\
-\quad \text { Urban } \\
-\quad \text { Rural } \\
\end{array}$ & $\begin{array}{l}66(14.3) \\
76(20.8)\end{array}$ & $\begin{array}{l}396(85.7) \\
290(79.2) \\
\end{array}$ & 0.014 \\
\hline $\begin{array}{ll}\text { Grades of past year: } \\
- & \text { Excellent / Very Good } \\
- & \text { Good / Pass } \\
- & \text { Failed (Repeat the year) }\end{array}$ & $\begin{array}{r}22(10.2) \\
114(19.1) \\
6(37.5) \\
\end{array}$ & $\begin{array}{r}194(89.8) \\
482(80.9) \\
10(62.5) \\
\end{array}$ & 0.001 \\
\hline $\begin{array}{ll}\text { Education of the father: } \\
\text { - } & \text { Illiterate / Read \& write } \\
\text { - } & \text { Basic / Secondary } \\
\text { - } & \text { University / Higher } \\
\end{array}$ & $\begin{array}{l}36(28.1) \\
36(12.9) \\
70(16.7) \\
\end{array}$ & $\begin{array}{r}92(71.9) \\
244(87.1) \\
350(83.3) \\
\end{array}$ & 0.001 \\
\hline \begin{tabular}{ll}
\multicolumn{2}{l}{ Education of the mother: } \\
- $\quad$ Illiterate / Read \& write \\
- $\quad$ Basic / Secondary \\
$-\quad$ University/ Higher \\
\end{tabular} & $\begin{array}{l}50(24.8) \\
48(16.6) \\
44(13.1) \\
\end{array}$ & $\begin{array}{l}152(75.2) \\
242(83.4) \\
292(86.9) \\
\end{array}$ & 0.002 \\
\hline 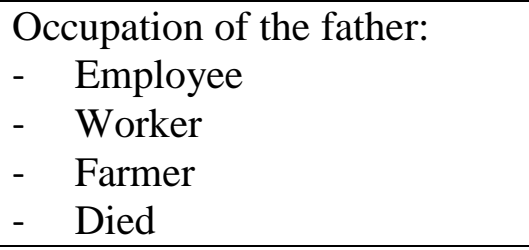 & $\begin{array}{l}84(14.8) \\
26(17.3) \\
16(26.7) \\
14(28.0) \\
\end{array}$ & $\begin{array}{r}482(85.2) \\
124(82.7) \\
44(73.3) \\
36(72.0) \\
\end{array}$ & 0.036 \\
\hline $\begin{array}{l}\text { Occupation of the mother: } \\
-\quad \text { Housewife } \\
-\quad \text { Employee } \\
\end{array}$ & $\begin{array}{r}108(20.8) \\
34(11.0) \\
\end{array}$ & $\begin{array}{l}412(79.2) \\
274(89.0)\end{array}$ & $<0.001$ \\
\hline $\begin{array}{l}\text { Consanguinity among parents: } \\
-\quad \text { Yes } \\
-\quad \text { No }\end{array}$ & $\begin{array}{l}84(15.3) \\
58(20.7)\end{array}$ & $\begin{array}{l}464(84.7) \\
222(79.3)\end{array}$ & 0.051 \\
\hline Total & $142(17.1)$ & $686(82.9)$ & $828(100)$ \\
\hline
\end{tabular}


Table (3): Distribution of mental distress among studied students by familial and habitual characteristics, Assiut university, 2017.

\begin{tabular}{|c|c|c|c|}
\hline \multirow{2}{*}{ Characteristics } & \multicolumn{2}{|c|}{ Presence of mental distress } & \multirow{2}{*}{$\begin{array}{c}P \text { - } \\
\text { value }\end{array}$} \\
\hline & Yes & No & \\
\hline $\begin{array}{ll}\text { Preference: } \\
-\quad \text { Son like daughter } \\
-\quad \text { Family prefers son } \\
-\quad \text { Family prefers daughter }\end{array}$ & $\begin{array}{r}124(16.2) \\
18(31.0) \\
0(0.0)\end{array}$ & $\begin{array}{r}642(83.8) \\
40(69.0) \\
4(100.0)\end{array}$ & 0.010 \\
\hline $\begin{array}{l}\text { Student live with: } \\
-\quad \text { The family } \\
-\quad \text { Away from the family }\end{array}$ & $\begin{array}{l}96(16.1) \\
46(19.8)\end{array}$ & $\begin{array}{l}500(83.9) \\
186(80.2)\end{array}$ & 0.202 \\
\hline $\begin{array}{l}\text { Family condition: } \\
-\quad \text { Both parent together } \\
-\quad \text { Only one parent is present }\end{array}$ & $\begin{array}{r}114(17.2) \\
28(16.9)\end{array}$ & $\begin{array}{l}548(82.8) \\
138(83.1)\end{array}$ & 0.914 \\
\hline $\begin{array}{l}\text { Presence of sibling: } \\
-\quad \text { Yes } \\
-\quad \text { No } \\
\end{array}$ & $\begin{array}{r}138(17.3) \\
4(13.3)\end{array}$ & $\begin{array}{r}660(82.7) \\
26(86.7)\end{array}$ & 0.572 \\
\hline $\begin{array}{l}\text { Marriage: } \\
-\quad \text { Single } \\
-\quad \text { Engaged/ Married } \\
\end{array}$ & $\begin{array}{r}130(16.9) \\
12(20.7)\end{array}$ & $\begin{array}{r}640(83.1) \\
46(79.3)\end{array}$ & 0.450 \\
\hline $\begin{array}{ll}\text { Perceived health status: } \\
-\quad \text { Excellent /Very good } \\
-\quad \text { Good } \\
-\quad \text { Average (fair) / Bad } \\
\end{array}$ & $\begin{array}{r}24(6.1) \\
64(20.9) \\
54(42.2) \\
\end{array}$ & $\begin{array}{r}368(93.9) \\
242(79.1) \\
74(57.8) \\
\end{array}$ & $<0.001$ \\
\hline $\begin{array}{l}\text { Presence of disability: } \\
-\quad \text { Yes } \\
-\quad \text { No }\end{array}$ & $\begin{array}{r}2(10.0) \\
140(17.3)\end{array}$ & $\begin{array}{r}18(90.0) \\
668(82.7)\end{array}$ & 0.390 \\
\hline $\begin{array}{l}\text { Smoking: } \\
-\quad \text { Yes } \\
-\quad \text { No } \\
\end{array}$ & $\begin{array}{r}24(19.4) \\
118(16.8)\end{array}$ & $\begin{array}{l}100(80.6) \\
586(83.2)\end{array}$ & 0.479 \\
\hline $\begin{array}{l}\text { Drug abuse: } \\
-\quad \text { Yes } \\
-\quad \text { No } \\
\end{array}$ & $\begin{array}{r}2(12.5) \\
140(17.2)\end{array}$ & $\begin{array}{r}14(87.5) \\
672(82.8)\end{array}$ & 0.618 \\
\hline $\begin{array}{l}\text { Exposure to violence: } \\
-\quad \text { Yes } \\
-\quad \text { No } \\
\end{array}$ & $\begin{array}{l}44(36.1) \\
98(13.9)\end{array}$ & $\begin{array}{r}78(63.9) \\
608(86.1) \\
\end{array}$ & $<0.001$ \\
\hline $\begin{array}{l}\text { History of mental problems: } \\
-\quad \text { Yes } \\
-\quad \text { No } \\
\end{array}$ & $\begin{array}{r}32(35.6) \\
110(14.9)\end{array}$ & $\begin{array}{r}58(64.4) \\
628(85.1) \\
\end{array}$ & $<0.001$ \\
\hline $\begin{array}{l}\text { Presence of hobbies: } \\
-\quad \text { Yes } \\
-\quad \text { No } \\
\end{array}$ & $\begin{array}{r}134(17.6) \\
8(11.8)\end{array}$ & $\begin{array}{r}626(82.4) \\
60(88.2) \\
\end{array}$ & 0.218 \\
\hline
\end{tabular}


Table (3): Distribution of mental distress among studied students by familial and habitual characteristics, Assiut university, 2017. Continued.

\begin{tabular}{|l|r|r|c|}
\hline \multirow{2}{*}{ Characteristics } & \multicolumn{2}{|c|}{ Presence of mental distress } & \multirow{2}{*}{ P - value } \\
\cline { 2 - 3 } & \multicolumn{1}{|c|}{ Yes } & \multicolumn{1}{c|}{ No } & \\
\hline $\begin{array}{l}\text { Difficulty in finding work after } \\
\text { graduation: }\end{array}$ & & & \\
$-\quad$ Yes & $120(21.2)$ & $446(78.8)$ & \\
$-\quad$ No & $22(8.4)$ & $240(91.6)$ & $<0.001$ \\
\hline Total & $142(17.1)$ & $686(82.9)$ & $828(100.0)$ \\
\hline
\end{tabular}

Table (4): Logistic regression analysis for variables related to mental distress among studied students, Assiut University, 2017.

\begin{tabular}{|l|l|l|}
\hline \multicolumn{1}{|c|}{ Variables } & \multicolumn{1}{|c|}{ Odds ratio (95\% CI) } & \multicolumn{1}{|c|}{ P-value } \\
\hline Education of the father: & & \\
- Illiterate / Read \& write & Reference & 0.025 \\
- Basic / Secondary & $1.195(.707-2.021)$ & 0.506 \\
- University / Higher & $0.576(.354-.935)$ & 0.026 \\
\hline Grades of past year: & & \\
(Excellent / Very Good) & $0.484(.282-.832)$ & 0.009 \\
\hline Perceived health status of student: & & \\
- Excellent / very good & Reference & 0.000 \\
- Good & $3.250(1.933-5.465)$ & 0.000 \\
$-\quad$ Average / bad & $8.266(4.650-14.695)$ & 0.000 \\
\hline Sex(Female) & $1.704(1.116-2.603)$ & 0.014 \\
\hline History of mental problems (Yes) & $3.212(1.817-5.676)$ & 0.000 \\
\hline Exposure to violence (Yes) & $2.524(1.550-4.112)$ & 0.000 \\
\hline Constant & 0.766 & 0.297 \\
\hline
\end{tabular}

R square: 26.1

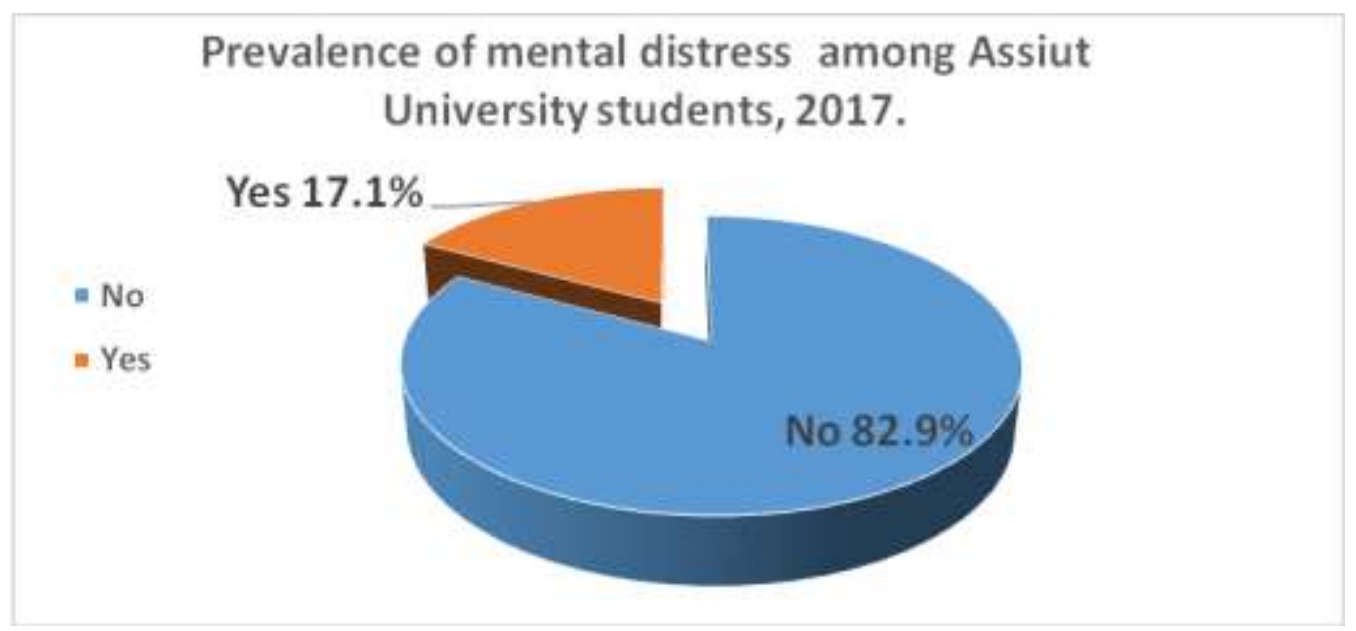

prevalence of mental distress than those with bad health status $(42.2 \%)(\mathrm{p}<0.001)$. Students with previous exposure to violence and those with family history of mental health problems had significantly higher prevalence of mental distress $(36.1 \%$ and $35.6 \%)$ respectively $(\mathrm{p}<0.001)$.

Table (4) shows that by logistic regression analysis, university and higher 
education of the parent and excellent or very good degree of the student in the past year was protective against mental distress among students. On the other hand, as the perceived health status of the student is deteriorated the prevalence of mental distress is increased. Also, female sex, family history of mental health problems and exposure to violence in the past increase the probability of mental distress among the students.

\section{Discussion}

Harding et al, 1980 documented that the prevalence of mental distress among the students was higher than the rates among general populations studied. ${ }^{10}$

Our result revealed that prevalence of mental distress is $17.1 \%$ among the studied students, this finding is nearly consistent with findings of other studies; in Campinas, Brazil $(17 \%)^{11}$, Ethiopia $(17.7 \%)^{12}$, Australia $(19.2 \%)^{13}$ and Somaliland $(19.8 \%){ }^{14}$ Furthermore, prevalence of mental distress was $7.1 \%$ among the SYPE (Survey of Young People in Egypt) respondents. ${ }^{9}$ The lower prevalence of mental distress among SYPE respondents $(7.1 \%)$ than that reported by this study $(17.1 \%)$ as it included participants of wider age groups (13 - 35 years) and it represents total Egypt.

The prevalence of mental distress reported in our sample is relatively lower than that recognized by other studies from USA $(57 \%)^{15}$, northwest Ethiopia $(40.9 \%)^{16}$, Malaysia $(41.9 \%)^{17}$, India $(30.39 \%)^{18}$, and France $(25.7 \%){ }^{19}$

On the other hand, many studies have documented that high prevalence of mental distress among medical students in low- and middle-income countries ranging from $41.9 \%$ in Malaysia $^{20}$, to $47.0 \%$ in southern India. ${ }^{21}$

This study found a prevalence of mental distress unlike the previous studies (high or low), [although the same tool was used by these studies (SRQ-20)], this difference could be due to the different cut off point used in other studies or it might be an actual difference due to cultural, behavioral and sociodemographic factors.

Many variables demonstrated an association with mental distress among Assiut university students were identified by multiple logistic regression analysis in this study.

Female students were more vulnerable to mental distress compared to the males, this is consistent with findings of many studies. $^{14,16,22}$ Furthermore, among females in developed countries mental distress represent the $3^{\text {rd }}$ health problem and the $5^{\text {th }}$ in undeveloped countries. ${ }^{23}$ Inam et al., 2003 reported that female students have higher rates of mental distress than males because they are more competitive, more worried to get more marks in examinations, and tend to engage in less exercise. ${ }^{24}$ Other studies pointed to pressures formed by their numerous tasks and responsibilities of women in addition to, gender based violence and discrimination. $^{25,26}$

This study showed that family history of mental illness is one of predictors of mental distress, this finding was supported by other studies. In a community-based study at Dhaka ${ }^{27}$ and among the young male university students of Tehran. ${ }^{28}$ Berihun et al, 2015 revealed that the probability of mental distress among respondents who had family history of mental distress were 2.12 times higher than those who have not. ${ }^{16}$ This might be due to genetic factors and living circumstances within the families. Furthermore, care of the mentally ill family member might be an added stress that contributes to a higher prevalence of mental distress. $^{29}$

This study shows significant association between bad perceived health status and mental distress, this was supported by other studies. ${ }^{12,30,31}$ Additionally, our result revealed that exposure to violence 
in the past increases the probability of mental distress among the students. This finding was compatible with Wagner et al., 2009 who pointed to exposure to violence was significantly associated mental distress. ${ }^{32}$

Moreover, the study revealed that high educational achievement of the student (excellent or very good) in the past year have protective effect against mental distress, this finding was supported by many studies. Berihun et al., 2015 reported that students whose grade was lower than expected were two times more liable to have mental distress than others. ${ }^{16}$ Similar results were reported by Bostani et al., 2014. ${ }^{33}$

Although, smoking behavior and mental health problems are highly correlated ${ }^{34,35}$, the result of this study found insignificant association between smoking and mental distress. Other studies found that nicotine dependency that contributes to stress rather than overall smoking itself. Regular smokers need to maintain their nicotine level in order to maintain normal mood and avoid the unpleasant feelings of withdrawal symptoms that could be misinterpreted as stress. $^{36,37}$

Unlike the previous studies ${ }^{14,16,38}$ our study revealed that drug abuse was insignificantly associated with mental distress. The difference could be attributed to different cultural, religious and traditional beliefs. In addition to the very low prevalence of drug abuse (1.9\%) among the study population, on the other hand, this study revealed that no difference regarding prevalence of mental distress between three faculties under study in contrast to a study that was conducted among Debre Berhan university students in Ethiopia which revealed that field of study was statistically significant risk factors of mental distress. ${ }^{39}$ This may be due that students in this study came from the same socio-demographic and cultural backgrounds.

\section{Conclusion}

A high proportion of Assuit University students suffer from mental distress $(17.1 \%)$. By using logistic regression analysis, the significant variables related to presence of mental distress were bad perceived health status, previous exposure to violence and family history of mental health problems. On the other hand, university or higher education of the parent, excellent or very good degree of the student in the past year were protective against mental distress among students.

\section{Recommendations}

It is recommended that mental distress needs more attention and counteractive action from policy makers, university administrators and parents. An intervention program is required to increase the awareness about mental distress among students, parents, policy makers and university administrators and to overcome the associated risk factors.

\section{References:}

1. WHO (2001): Mental health: New understanding; new hope WHO, Geneva. The World Health Report 2001.

2. Sadock BJ, Virginia AS, Pedro R. (2009): Kaplan and Sadock's comprehensive textbook of psychiatry. 9th ed. Philadelphia: Lippincott Williams \& Wilkins;2009

3. Gebru AA, Berhe KK, Gebr HB. (2014): Assessment of prevalence and associated factors of mental distress among first year regular students of Mekelle University main campus, Mekelle City 2010/ 11; a cross sectional study. Am J AdvNurs Res.;1(1):5-14.

4. Svanum S, Zody ZB.(2001): Psychopathology and college grades. J Couns Psychol. 48:72-6.

5. Benton, S. A., Robertson, J. M., Tseng, W., Newton, F. B., \& Benton, S. 
L. (2003): Changes in counseling center client problems across 13 years. Professional Psychology: Research and Practice, 34, 6672.

6. Kessler RC, Frank RG. (1997): The impact of psychiatric disorders on work loss days. Psychological medicine, 1997, 27:86173.

7. Samouei R, Fooladvand M, Janghorban S, Khorvash F. (2015): Predicting the educational performance of Isfahan University students of medical sciences based on their behavior profile, mental health and demographic characteristic. J Educ Health Promot.;4:44.

8. WHO (1994): A user 's guide to the Self Reporting Questionnaire (SRQ). Division of mental health, WHO, Geneva.

9. Roushdy R. and Sieverding M (2015): Panel Survey of Young People in Egypt: Generating Evidence for Policy and Programs. Cairo, Egypt: Population Council.www.popcouncil.org

10.Harding TW, de Arango MV, Baltazar J, Climent CE, Ibrahim HH, Ladrido-Ignacio L (1980): Mental disorders in primary health care: a study of their frequency and diagnosis in four developing countries. Psychol Med.;10(2):231-41.

11.Lima MC, Domingues MS, Cerqueira AT. (2006): Prevalence and risk factors of common mental disorders among medical students. Rev SaúdePública;40(6):1035-41.

12.Bizu, SL, Negussie D, Yonas B, Markos T, Yemane B and Michelle I(2012): Prevalence and correlates of mental distress among working adults in Ethiopia. Clinic Practice Epidemiol in Mental H, 8, 126-133.

13.Stallman HM. (2010): Psychological distress in university students: a comparison with general population data. Australian Psychologist; 45(45):249-257.

14.LibanHersi, KenfeTesfay, HailayGesesew, Deria Ereg1 and Markos Tesfaye(2017):Mental distress and associated factors among undergraduate students at the University of Hargeisa, Somaliland: a crosssec study. International J. of Mental Health Systems. 11:39

15. Mosley TH, Perrin SG, Neral SM, Dubbert PM. (2008): Stress,coping, and well-being among third-year medical students. Acad Med; 69 (9): 765 -767.
16.Berihun Assefa Dachew, Telake Azale Bisetegn, Resom Berhe and Gebremariam (2015): Prevalence of Mental Distress and Associated Factors among Undergraduate Students of University of Gondar, Northwest Ethiopia: A Cross-Sectional Institutional Based Study.

17.MohdS,S., RampalL, Kaneson N. (2008): Prevalence of emotional disorders among medical students in a Malaysian university. Asia Pacific Family Medicine; 2(4):213-217. 18.Christofer T. (2014): Assessment of Mental Distress in Undergraduate Medical Students. Journal of Educational Research \& Medical Teacher;2(1):14-17 14

19. Verger P, Combes JB, Kovess-Masfety V. (2009): Psychological distress in first year university students: socioeconomic and academic stressors, mastery and social support in young men and women. Social Psychiatry and Psychiatric Epidemiology; 44:643-650.

20.Al-Naggar RA, Al-Naggar DH. (2012): Prevalence and associated factors of emotional disorder among Malaysian University students. Int J Collab Res Intern Med Public Health; 4:1401-11.

21.Mannapur B, Dorle AS, Hiremath LD, Ghattargi CH, Ramadurg U, Kulkarni KR. (2010): A study of Psychological stress in undergraduate medical students at SN Med. College. J ClinDiagn Res. 4: 2869 -74.

22.Mohammad I, Imran K, Robinaarwar (2016): prevalence of mental illnesses in public sector medical college, Peshawar. j med sci vol. 24, no.

23.Ludermir AB, MeloFilho DA. (2002): Living conditions and occupational organization associated with common mental disorders. Rev Sa Puplica. 36(2):213-21.

24.Inam SNB, Saqib A, Alam E. (2003): Prevalence of anxiety and depression among medical students of private university. J Pak Med Assoc; 53(2): 44-7.

25.WHO (2002): Gender disparities in mental health. World Health Organization. Department of Mental Health, and Substance Dependence. Geneva, Switzerland.

26.Krieger N, Waterman PD, Hartman C, (2006): Social hazards on the job: workplace abuse, sexual harassment, and racial discrimination study of Black, Latino, and White low-income women and men workers 
in the United States. Int J Health Serv; 36 (1): 51-85.

27.Verger P, Combes JB, Kovess-Masfety $\mathrm{V}$, Choquet M, Guagliardo V, Rouillon F (2009): Psychological distress in first year university students: Socioeconomic and academic stressors, mastery and social support in young men and women. SocPsychiatEpidemiol; 44:643-50

28. Shariati M, Yunesian M, Vash JH. (2007): Mental health of medical students: A cross-section. study in Tehran. Psychol Rep; 100: 346-54.

29.Begg S, Vos T, Barker B, Stevenson C, Stanley L, \&, Lopez AD. (2007): Burden of disease and injury in Australia. Canberra: AIHW.

30.Costa EF, Santana YS, Santos AT, Martins LA, Melo EV, Andrade TM. (2012): Depressive symptoms among medical intern students in a Brazilian public university. Rev Assoc Med Bras;58(1):53-9.

31.Dusselier L, Dunn B, Wang Y, Shelley MC 2nd, Whalen DF, (2005): Personal, health, academic, and environmental predictors of stress for residence hall students. J Am Coll Health;54 (1):15-24.

32.Wagner S. Ribeiro; Sergio B. Andreoli; Cleusa P. Ferri; Martin Prince and Jair Jesus Mari(2009): Exposure to violence and mental health problems in low and middleincome countries: a literature review Rev. Bras. Psiquiatr. vol.31 supl.2.

33.Mehdi B,Amir Nand Azami R.N. (2014):A Study of the Relation between
Mental health and Academic Performance of Students of the Islamic Azad University Ahvaz Branch. procedia-social and behavioral sciences. volume 116.pages 163165.

34. Mykletun A, Overland S, Aaro LE, Liabo HM, Stewart R (2008). Smoking in relation to anxiety and depression: Evidence from a large population survey: The HUNT study. EurPsychiatr, 23, 77-84

35.Boden J, Fergusson D, Horwood L (2010): Cigarette smoking and depression: tests of causal linkages using a longitudinal birth cohort. Br J Psychiatry, 196, 440-46.

36.Parrott AC (1999): Does cigarette smoking cause stress? Am Psychol, 54, 81720.

37. Meray MS and Ahmed FH, Rania AR (2016): Study of Drug Abuse among University Students in Sohag, Egypt. Journal of Forensic, Toxicology and Medicolegal Analysis;1(2): 19-23

38.Saravanan C \&Heidhy I (2014): Psychological Problems \& Psychosocial Predictors of Cigarette Smoking Behavior among Undergrad Students in Malaysia. Asian Pac J Cancer Prev, 15 (18), 7629-7634 39. Haile YG, Alemu SM and Habtewold TD (2017):Common mental disorder and its association with academic performance among DebreBerhan University students, Ethiopia.Int J Ment Health Syst 11:34.DOI 10.1186/s13033-017-0142-6. 